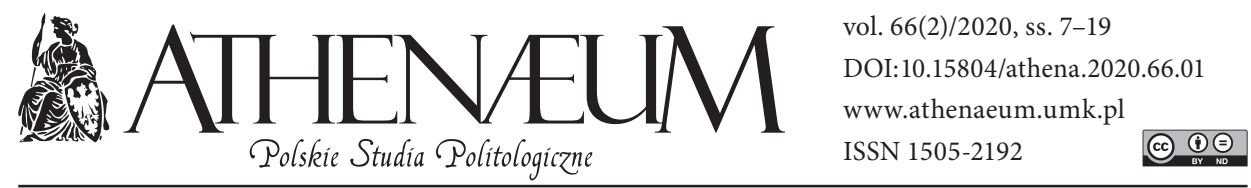

\title{
IZBY DRUGIE PARLAMENTU PAŃSTW BYŁEJ JUGOSŁAWII
}

\author{
SECOND CHAMBERS OF PARLIAMENTS OF THE FORMER \\ YUGOSLAVIA
}

Magdalena Maksymiuk* [1]

\begin{abstract}
ABSTRAKT
Niniejsza praca jest prezentacją drugich izb parlamentu w krajach byłej Jugosławii, jakimi są Słowenia oraz Bośnia i Hercegowina. Jako jedyne w regionie zdecydowały się one na przyjęcie bikameralnego porządku w ramach władzy ustawodawczej. Pomimo bliskości geograficznej i wspólnej historii ustrojodawcy obu państw postanowili przyjąć znacząco inny, oryginalny kształt porównywanych do siebie ciał ustawodawczych, wyróżniających się na skalę światową. Co więcej, każda $\mathrm{z}$ nich została obdarzona różnymi kompetencjami, z czego wynika pozycja wobec pierwszej izby parlamentu, a także pozostałych organów władzy państwowej. Artykuł ten stanowi więc przekrój i pogłębioną charakterystykę polityczno- prawną Izby Narodów Bośni i Hercegowiny oraz Rady Państwa Słowenii, a także zawiera propozycje zmian systemowych.
\end{abstract}

Słowa kluczowe: drugie izby; parlament; Jugosławia; Bośnia i Hercegowina; Słowenia
ABSTRACT

This work presents the second houses of parliaments in the countries of former Yugoslavia, such as Slovenia and Bosnia and Herzegovina. As the only ones in the region, they decided to adopt a bicameral order within the legislative power. Despite the geographical proximity and common history, the legislators of both countries decided to adopt a different, original shape of the bodies compared to each other. It stands out on a global scale. Moreover, each of them was endowed with different competences, which results in their position in relation to the first chamber of parliament as well as to other state organs. This article therefore constitutes a cross-section and in-depth political and legal description of the Chamber of Nations of Bosnia and Herzegovina and the Council of State of Slovenia, and proposes systemic changes.

Keywords: second chambers; parliament; Yugoslavia; Slovenia; Bosnia and Hercegovina

\footnotetext{
* Uniwersytet Kardynała Stefana Wyszyńskiego, Instytut Nauk o Polityce i Administracji.
} 


\section{WSTĘP}

Jugosławia to byłe państwo, które w swoich granicach mieściło narody zaliczane do grupy południowosłowiańskiej. Sama jego nazwa używana była do 1918 roku w odniesieniu do koncepcji politycznej. Następnie sformułowania tego używano, określając Królestwo Serbów, Chorwatów i Słoweńców, Królestwo Jugosławii, a także Socjalistyczną Federacyjną Republikę Jugosławii. Po rozpadzie, zapoczątkowanym w latach 80. XX wieku, po śmierci Josipa Broza Tito, ostatecznie na tych terenach swoją suwerenność zyskały Słowenia, Chorwacja, Macedonia, Bośnia i Hercegowina, Serbia oraz Czarnogóra (Rycerska, 2003 s. 23; Pioruńska, 2010, s. 27-34).

Państwa te stanęły przed trudnym zadaniem ukonstytuowania nowych, odrębnych systemów polityczno-prawnych. W kwestiach władzy ustawodawczej, jedną z najważniejszych było podjęcie decyzji o unikameralnym bądź bikameralnym kształcie parlamentu. Początkowo na strukturę dwuizbową zdecydowały się trzy państwa, a były to Bośnia i Hercegowina, Słowenia i Chorwacja, jednakże ta ostatnia zrezygnowała z drugiej izby parlamentu nowelą konstytucyjną z 2001 roku (Składowski, 2013, s. 81-84).

Nawiązując do krótkiego wstępu, przedmiotem niniejszej pracy jest prezentacja drugich izb parlamentu w Bośni i Hercegowinie oraz Słowenii. Artykuł prezentuje okoliczności, w jakich doszło do stworzenia opisywanych organów władzy państwowej, ich pozycję ustrojową, skład oraz kompetencje. Pozwoli to ocenić, czy państwa te dokonały słusznego wyboru, tworząc parlament bikameralny.

Powyższe cele skłoniły mnie do sformułowania hipotezy, która wskazuje, że ustanowienie drugich izb parlamentu w opisywanych państwach, pozwoliło na stworzenie alternatywy dla modelu jednoizbowego. Daje ona nowe możliwości realizacji funkcji parlamentarnych, przez co izby drugie stały się niezbędne w zakresie władzy ustawodawczej. Hipotezą pomocniczą zdaje się być tutaj kwestia wypracowania własnej i oryginalnej konstrukcji prawnej izby, która odpowiada potrzebom ustrojowym państwa. Podjęta pod rozwagę zostanie także kwestia, czy obecny kształt drugich izb w tych państwach jest adekwatny do sytuacji politycznej, odpowiada współczesnym potrzebom i czy powinien być ostateczny?

Postawione przeze mnie cele pracy odzwierciedlają funkcje nauk politologicznych. Jako pierwszą z nich postanowiłam wskazać deskrypcję, co w pracy przejawia się jako charakterystyka rozwiązań ustrojowych drugich izb parlamentu Słowenii oraz Bośni i Hercegowiny. Ciekawym wydaje się być tutaj także 
ujęcie komparatystyczne regulacji prawnych. Pozwala bowiem wskazać, że pomimo wspólnej historii państw pojugosławiańskich, wybrały one inną drogę, nie tylko w zakresie wyboru jedno- czy dwuizbowości, ale także w kwestii pozycji ustrojowej izby drugiej, jej kształtu i realnej możliwości kompetencyjnej.

Współcześnie politolodzy, aby odpowiedzieć sobie na wyżej zadane pytania, posługują się badaniem politologicznym, na które, oprócz wyżej wspomnianej metody porównawczej, składa się metoda instytucjonalno-prawna, która pozwala scharakteryzować poszczególne elementy izb, a także metoda opisowa i systemowa dla wskazania złożoności systemu politycznego państwa oraz wyróżnienia i wskazania miejsca w nim danej izby (Biernat, 1978, s. 95-96).

\section{MIEJSCE DRUGICH IZB PARLAMENTU W USTROJU POLITYCZNYM PAŃSTWA}

Na przyjęty kształt systemów politycznych nowo powstałych państw z terenu byłej Jugosławii miało wpływ zróżnicowanie etniczne i religijne, jakim charakteryzuje się ten region. Bośnia i Hercegowina jest jedynym państwem, będącym niegdyś w składzie Socjalistycznej Federacyjnej Republiki Jugosławii, która nie posiada zewnętrznych granic. $Z$ tego też powodu składała się $\mathrm{z}$ wielu narodowości i nazywano ją „Jugosławią w miniaturze”, co przełożyło się na kształt izby drugiej parlamentu (Vlaisavlević, 2009, s. 165-166).

Obecny porządek ustrojowy Bośni i Hercegowiny jest jednym z najbardziej skomplikowanych na świecie. Dzieje się tak, ponieważ jest ona państwem, które zamieszkują trzy narody wymienione już nawet w ustawie zasadniczej, a są nimi Serbowie, Chorwaci i Bośniacy. Administracyjnie składa się ona z dwóch entientów Republiki Serbskiej oraz Federacji Bośni i Hercegowiny, a także autonomicznego Dystryktu Brčko. Sytuacja narodowościowa w tym państwie odzwierciedla się w strukturach organów administracji publicznej. Ustrój polityczny został wypracowany na mocy porozumienia z Dayton, a konstytucja, która stanowi Aneks IV do dokumentu, miała na celu osiągnięcie pokoju (Stanisławski, 2008, s. 42). Planowano, że będzie to akt tymczasowy, do momentu znalezienia bardziej kompatybilnego rozwiązania. Tak wypracowany porządek pod wieloma względami skomplikowany i niezrozumiały, obowiązuje do dziś. Reprezentanci trzech skonfliktowanych stron, mając przekonanie o tymczasowości układu, mieli na celu dbanie wyłącznie o swój interes i ochronę rodaków (Krysieniel, 2012, s. 270). 
Na poziomie państwowym funkcjonuje dwuizbowy parlament, który dzieli się na Izbę Reprezentantów i Izbę Narodów. Ta ostatnia składa z 15 członków, po 5 dla każdej narodowości. Kadencja trwa 4 lata. Zgodnie z podziałem narodowym w izbie, wybiera ona jednego Bośniaka, Serba i Chorwata, którzy to rotacyjnie obejmują stanowisko przewodniczącego (Konstytucja Bośni i Hercegowiny, art. IV ust 3; Regulamin Izby Narodów, art. 22; Markiewicz, 2008, s. 187). Ważny, z punktu widzenia struktury, stał się podział na narodowości. Wszystkie akty prawne przyjęte przez izbę, materiały informacyjne, dokumenty czy protokoły sporządzane są odrębnie w językach bośniackim, chorwackim i serbskim (Regulamin Izby Narodów, art. 183).

Co warto podkreślić, ze względu na wymóg wyrażenia zgody na uchwalanie aktów prawnych przez obie izby parlamentu mamy w tym przypadku do czynienia $\mathrm{z}$ bikameralizmem zrównoważonym. Każde z ciał prawodawczych zajmuje równie ważne miejsce w systemie konstytucyjnym państwa.

Sposób wyboru członków izby stanowi przykład panującej w państwie etnokracji i po trosze wynikającej z tego niesprawiedliwości. Da się bowiem zauważyć brak jednolitości w elekcji deputowanych, będących reprezentantami poszczególnych narodowości. Przedstawiciele Bośniaków i Chorwatów są wybierani wyłącznie przez bośniackich i chorwackich posłów Izby Narodów Federacji, zaś serbscy przedstawiciele odpowiednio przez wszystkich członków Skupsztiny Ludowej Republiki. Należy także podkreślić, że w izbie reprezentowane są jedynie narody konstytutywne. Nie ma w niej miejsca dla mniejszości (Nystuten, 2005, s. 144). Deputowani do Izby Narodów mają prawo uczestniczyć w sesjach izby oraz organów roboczych, nawet tych, których nie są członkiem (lecz bez prawa głosu). Wyjątek stanowi tutaj Wspólna Komisja Nadzoru Agencji Wywiadu i Bezpieczeństwa BiH. Delegaci mają prawo inicjatywy ustawodawczej, mogą nawet proponować zmiany do Konstytucji (Regulamin Izby Narodów, art. 8 i 10), co jest ważną kompetencją oraz wyróżnikiem.

Dla podjęcia decyzji niezbędne jest kworum, które wynosi 9 delegatów, pod warunkiem, że obecnych jest co najmniej po 3 delegatów każdego narodu. Decyzje podejmuje się większością głosów (Regulamin Izby Narodów, art. 63 i 75).

W ramach izby działają trzy kluby ludów, odpowiadające reprezentantom narodów, występujących w ramach Bośni i Hercegowiny:

1. Klub delegatów narodu bośniackiego;

2. Klub delegatów narodu chorwackiego;

3. Klub delegatów narodu serbskiego. 
Powstały one dla urzeczywistnienia formy działalności roboczych deputowanych izby. Do ich zadań należy m.in. przygotowanie sesji izby czy ustanawianie porządku obrad. Spośród swoich członków wybierają oni przewodniczącego oraz wiceprzewodniczącego (Regulamin Izby Narodów, art. 4-5).

Izba ma swojego przewodniczącego oraz dwóch wiceprzewodniczących. Każdy z nich jest reprezentantem innego narodu. Kluby przedstawiają propozycje wyboru przewodniczącego i wiceprzewodniczących. Izba mianuje również sekretarza (Regulamin Izby Narodów, art.7). Co więcej, przewodniczący, dwóch wiceprzewodniczących, prezesi klubów delegatów narodowych oraz sekretarz izby ludowej tworzą Kolegium Izby Narodów (Regulamin Izby Narodów, art. 17).

W ramach izby działają stałe i okazjonalne ciała robocze, jakimi są komisje. Pracują one, by rozpatrywać projekty ustaw oraz inne akty normatywne. Wykonują także inne zlecone im zadania. Przewodniczący oraz zastępca zostają wybrani spośród członków komisji, ale przy zachowaniu zasady, że każdy z nich pochodzi z innego klubu narodowego. Liczbę członków ustala się przy powoływaniu ciała, jednak nie mogą liczyć więcej niż 9 członków. Tutaj również organy robocze wybierają tę samą ilość Bośniaków, Serbów i Chorwatów oraz odpowiednią liczbę z reszty członków izby.

Do stałych komisji działających w ramach izby należą:

1. Komisja Prawa Konstytucyjnego;

2. Komitet ds. Polityki Zagranicznej i Handlowej, Ceł, Transportu i Komunikacji;

3. Komitet Finansów i Budżetu (Regulamin Izby Narodów, art. 26 i 38).

Izba na podstawie swojej wewnętrznej decyzji, na wniosek klubu lub delegatów, ma prawo ustanowić tymczasowe, problemowe komisje wewnątrz izby, a na wniosek Izby Reprezentantów komisję wspólną. Mogą one dotyczyć przygotowania określonego aktu normatywnego lub odpowiedzi na pytania, a także przyjąć charakter komisji śledczych (Regulamin Izby Narodów, art. 25).

Organy robocze Izby Narodów odbywają wspólne sesje z odpowiednimi ciałami Izby Reprezentantów, dla omawiania kwestii będących ich wspólnym interesem (Regulamin Izby Narodów, art. 48). Obie izby mogą także ustanawiać stałe lub tymczasowe wspólne komórki, które zajmują się doraźną pomocą w pracach parlamentarnych.

Obradują one w ramach poniższych komisji wspólnych:

1.Wspólna Komisja Obrony i Bezpieczeństwa BiH;

2. Wspólna Komisja Nadzoru Agencji Wywiadu i Bezpieczeństwa BiH; 
3. Wspólna Komisja ds. Reformy Gospodarczej i Rozwoju;

4. Wspólna Komisja ds. Integracji Europejskiej;

5. Wspólna Komisja Spraw Administracyjnych;

6. Wspólna Komisja Praw Człowieka.

Ponadto obie izby parlamentarne organizują oraz ustanawiają wspólny Sekretariat Zgromadzenia Parlamentarnego Bośni i Hercegowiny, dla skonsolidowania, a także ułatwienia prac ich obu (Regulamin Izby Narodów, art. 186).

Izba Narodów może zostać rozwiązana decyzją Prezydencji Bośni i Hercegowiny lub jej samej, większością głosów delegatów z co najmniej dwóch narodów. Taki wniosek może złożyć minimum 3 deputowanych. Co warte podkreślenia, w decyzji tej nie bierze udziału pierwsza izba parlamentu. Nie nadano więc jej prawa do skrócenia kadencji Izby Narodów, co po raz kolejny potwierdza brak zwierzchności jednego z ciał parlamentarnych nad drugim (Regulamin Izby Narodów, art. 179).

W Słowenii proces przemian ustrojowych przebiegał łagodniej w porównaniu do Bośni i Hercegowiny oraz innych państw regionu. Wpłynęła na to niewątpliwie jednolitość społeczeństwa słoweńskiego, dojrzałość elity politycznej w tym państwie, ale także położenie geograficzne. Oderwanie się Słowenii od Serbii nie było dla tych drugich tak znaczące, jak utrata wpływów w Bośni i Hercegowinie czy Chorwacji (Wiatr, 1998, s. 12). Jest ona drugim państwem w ramach byłej Jugosławii, które w swojej strukturze może poszczycić się parlamentem dwuizbowym. Dyskusje nad modelem legislatywy, a szczególnie forma drugiej izby, były jednym z najważniejszych tematów, podczas uchwalania ustawy zasadniczej. Władza ustawodawcza podzielona została na Zgromadzenie Państwowe oraz Radę Państwa, która swoim składem nie wpisuje się w powszechnie rozumiany schemat izby drugiej. Warto podkreślić, że rozwiązanie, jakie przyjęto w ramach jej struktury, jest oryginalne i wyróżniające ją spośród porządków przyjętych w państwach europejskich o bikameralnej strukturze parlamentu. Zwolennicy rozwiązania dwuizbowego w Słowenii tłumaczyli zasadność jej powołania potrzebą wyrażenia interesów przez społeczności lokalne i grupy zawodowe. Pozwala to zachować odmienne spojrzenie na różne kwestie podejmowane przez pierwszą izbę (Rybicki, 2012, s. 42-43).

Zapisy art. 96 Konstytucji Słowenii wskazują, że skład drugiej izby parlamentu nawiązuje do neokorporacjonizmu i zasad reprezentacji funkcjonalnej. Stanowi ona bowiem wyraz reprezentacji grup zawodowo-społecznych, a także niepolitycznych. Liczy 44 członków, z których połowa to reprezentanci lokalnych interesów, 4 reprezentuje pracodawców, kolejnych 4 pracowników. Z kolejnej 
„czwórki” dwóch reprezentuje rolników, jeden zawody rzemieślnicze i także jeden wolne zawody. Ostatnie 6 miejsc zostało podzielonych przez przedstawicieli uniwersytetów, nauczycieli, naukowców, opieki zdrowotnej i społecznej, a także jeden wspólny dla przedstawicieli kultury i sportu. Co do zasady kadencja trwa 5 lat i nie bez przypadku, nie pokrywa się ona $\mathrm{z}$ kadencją Zgromadzenia Narodowego (Konstytucja Słowenii, art. 96; Rybicki, 2012, s. 43; Krysieniel, 2005). Różnica w jej długości ma na celu wzmocnienie i stabilizację izby drugiej w całym porządku ustrojowym państwa (Rybicki, 2012, s. 43).W przypadku, gdy termin kadencji upływa w czasie wojny lub stanu wyjątkowego, kadencja wydłuża się do czasu jego zakończenia i jeszcze przez sześć miesięcy. Kadencja upływa wraz z momentem rozpoczęcia pierwszej sesji nowego składu izby (Ustawa o Radzie Narodowej, art. 3).

Opisana wyżej struktura Rady Narodowej instytucjonalizuje procesy lobbingowe i w pewnym sensie je legalizuje. Zadaniem izby ma być odzwierciedlanie struktury społecznej Słowenii. Właśnie w podziale mandatów zawiera się idea doktrynalna Słowenii. Rada Państwa miała być gremium doradczym rady mędrców. Miało to stanowić miejsce, gdzie grupy społeczne, ekonomiczne lub zawodowe będą miały szanse przedstawiać swoje interesy na poziomie państwowym. Trzecim pomysłem była idea izby regionów. Dlatego właśnie największą liczbę członków stanowią reprezentanci gmin. Skład Rady Narodowej nawiązuje do czasów jugosłowiańskich. Miał on łączyć tradycje socjalistycznej Jugosławii oraz Słowenię z lat 1990-1992, kiedy istniała Izba Pracy Zespolonej i Izba Gminna. Przedstawiciele poszczególnych zawodów oraz przewodniczących społeczności lokalnych wybiera się w sposób bezpośredni, jednak na innych zasadach (Mikuli, 2003, s. 9-12). Bierne prawo wyborcze przysługuje obywatelowi, który nie jest pozbawiony praw wyborczych i ma ukończone 18 lat. Określenie czynnego prawa wyborczego nie jest już takie proste, ponieważ wybór 18 członków nie został określony przez poszczególne grupy zawodowe, których zadaniem jest wyłanianie swoich reprezentantów. Składają się one z przedstawicieli zainteresowanych organizacji oraz społeczności lokalnych. Co ciekawe, prawo głosu otrzymali również obcokrajowcy, przynależący do którejś z grup zawodowych i są zatrudnieni na terenie Słowenii (Sokół, Grylak, 2005, s. 527; Mikuli, 2003, s. 9-12). Pozostałych 22 członków, przedstawicieli władz lokalnych, wybiera się w specjalnie zorganizowanych okręgach wyborczych, które zostały podzielone, ze względu na wskaźniki geograficzne, historyczne i procentowe. Wyboru dokonują również kolegia, które reprezentują gminy wchodzące w skład okręgu wyborczego. Ich ilość zależy od liczby ludności (Ustawa o Radzie Narodowej, art. 11). 
Co warte podkreślenia, funkcja członka Rady Narodowej jest honorowa i społeczna, $z$ wyjątkiem przewodniczącego. Powodem tego jest pochodzenie z wyboru spośród przedstawicieli interesariuszy. Deputowani, w trakcie sprawowania mandatu, otrzymują jedynie zwrot utraconych dochodów, gdy pełnienie funkcji wpływa na pracę zawodową, a także poniesionych kosztów, takich jak przejazdy czy noclegi.

Organami izby jest Przewodniczący, jego zastępca, sekretarz, prezydium oraz komisje. Przewodniczącemu w zakresie wypełniania swoich obowiązków pomaga Wiceprzewodniczący (Ustawa o Radzie Narodowej, art. 62). Pierwszemu posiedzeniu izby przewodniczy jego najstarszy członek (Rybicki, 2012, s. 55-56).

Prace parlamentarne wewnątrz izby odbywają się głównie w komisjach. Z uwagi na małą liczebność członków izby, w zasiada w nich od 5 do 10 osób. Co warto podkreślić, wymagane przez prawo jest stworzenie jednej komisji - do spraw wykonywania mandatu oraz ochrony immunitetowej. Powołanie pozostałych jest fakultatywne i zależy od potrzeb izby. Poszczególne sprawy zostają przekazywane do odpowiednich kompetencyjnie komisji przez przewodniczącego izby. Ma ona za zadanie sporządzić raport, a także przedstawić go na forum Rady Narodowej (Ustawa o Radzie Narodowej, art.45).

W obecnej chwili na łamach izby funkcjonują poniższe komisje:

1. Komisja ds. Mandatu i Immunitetu;

2. Komisja ds. Regulacji Państwowych;

3. Komisja ds. Stosunków Międzynarodowych i Spraw Europejskich;

4. Komisja ds. Gospodarki, Rzemiosła, Turystyki i Finansów;

5. Komisja ds. Kultury, Nauki, Edukacji i Sportu;

6. Komisja ds. Opieki Społecznej, Pracy, Zdrowia i Osób niepełnosprawnych;

7. Komisja ds. Samorządu Lokalnego i Rozwoju Regionalnego;

8. Komisja ds. Rolnictwa, Leśnictwa i Żywności (Komisje, http://www.ds-rs. si/?q=kdo-smo/komisije).

\section{KOMPETENCJE DRUGICH IZB PARAMENTU}

Pozycję drugich izb w systemach ustrojowych państw wyznaczają nadane im kompetencje i -co z tego wynika - relacje, jakie występują między nimi a izbami pierwszymi oraz pozostałymi organami władzy.

Izba Narodów w Bośni i Hercegowinie ściśle współpracuje z Izbą Reprezentantów w zakresie przyjmowania Konstytucji, ustaw, budżetu i interpretacji prawa. 
Posiada inicjatywę ustawodawczą. Projekty mogą składać delegaci, kluby lub ciała robocze izby (Regulamin Izby Narodów, art. 94). Do izby drugiej mogą także wpływać wnioski ustawodawcze, które to później przesyłane są Prezydentowi i Wiceprezydentom, a także Przewodniczącemu Izby Reprezentantów. Oznacza to, że proces legislacyjny może rozpocząć się w obu ciałach parlamentarnych i mają one tożsamą moc sprawczą, by procedować prawo. Druga izba bierze także udział w procedowaniu prawa w trybie pilnym (Regulamin Izby Narodów, art. 95-96 oraz 123-124) oraz, co ważne, w procesie zmiany konstytucji. Poprawki do niej są zgłaszane na takiej samej zasadzie, jak w przypadku zwykłej procedury ustawodawczej. Pozwala to jeszcze raz potwierdzić równość kompetencyjną obu izb parlamentu (Regulamin Izby Narodów, art. 131).

Projekt i rozliczenie budżetu państwa należy do kompetencji rządu, na wniosek premiera. Początkowo jest on rozpatrywany przez Izbę Reprezentantów, co z kolei zostaje przekazywane do przewodniczącego izby z wyjaśnieniem. Prezydencja Bośni i Hercegowiny przedkłada izbie sprawozdanie o wykonaniu budżetu (Regulamin Izby Narodów, art. 127 i 129).

W kwestiach współpracy z władzą wykonawczą Rada Ministrów odpowiada przed izbą za proponowanie i wdrażanie polityki, przepisów ustawowych oraz innych aktów. Przekazuje ona także, w zakresie swoich kompetencji, wszystkie istotne informacje. Izba Narodów ma prawo okazać brak zaufania do rządu lub możliwości odbudowy Rady Ministrów. Z takim wnioskiem może wystąpić co najmniej trzech deputowanych izby, a Przewodniczącemu Rady Ministrów przysługuje możliwość wyjaśnienia motywów swojego postępowanie w izbie. Delegaci mogą zaproponować także usunięcie ze stanowiska jednego z ministrów (Regulamin Izby Narodów, art. 140,141,149). Izba wyraża również stanowisko, za pomocą rezolucji, w kwestiach politycznych oraz ustanawia wytyczne, które później zostają wdrożone przez Prezydencję Bośni i Hercegowiny, Radę Ministrów oraz inne instytucje. Deputowani mogą zadawać pytania ustnie lub pisemnie (jak np. interpelacje) skierowane do Rady Ministrów. Co najmniej raz w roku organizowana jest wspólna sesja obu izb parlamentu, na której to zadawane są pytania Radzie Ministrów przez członków obu ciał parlamentarnych (Regulamin Izby Narodów, art. 151,154-156, 160). Rada Ministrów może przedkładać izbie projekty ustaw oraz wnioskować o zwołanie sesji izby dla rozważania kwestii jej dotyczących. Członkowie Rady Ministrów mogą także uczestniczyć w posiedzeniach komisji. Do jej obowiązków należy także przekazywanie izbie sprawozdania ze swojej pracy, co najmniej raz w roku, które podlega rozpatrzeniu. Marszałek zaprasza na każdą sesję izby Prezydencję Bośni i Hercegowiny, 
z czego przynajmniej jeden z członków jest zobowiązany w nich uczestniczyć, gdy rozpatrywany jest projekt przepisów przez nią zaproponowany lub gdy rozstrzygane są kwestie wchodzące w zakres kompetencji tego organu (Regulamin Izby Narodów, art. 166, 168, 171-172). Prezydencja Bośni i Hercegowiny składa izbie wniosek o zgodę na ratyfikację lub wypowiedzenie ratyfikowanych umów międzynarodowych, konwencji oraz porozumień (Regulamin Izby Narodów, art. 130).

Obie izby parlamentarne, z uwagi na swój równorzędny charakter, współpracują ze sobą ściśle w zakresie kompetencji nadanych władzy ustawodawczej. Zgromadzenie Parlamentarne, na które składają się obie izby, tworzy specjalne i niezależne organy dla zapewnienia niezbędnej pomocy administracyjnej i technicznej.

W związku z tak przyjętym składem izby drugiej parlamentu w Słowenii, ustawodawca zdecydował się nadać jej dość okrojone kompetencje. W dużej mierze sprowadzają się one do kwestii doradczo-konsultacyjnych względem izby pierwszej. Nie została ona obdarzona funkcją kontrolną ani kreacyjną, a jej udział w procesie ustawodawczym jest bardzo ograniczony. Zauważyć da się jednak coraz częściej wysuwane przez samorządy zawodowe postulaty opowiadające się za zwiększeniem roli izby drugiej w całym systemie ustrojowym Słowenii (Patyra, 2001, s. 245; Mansfeldová, 2011, s. 132). Ustawa zasadnicza w swoim 97 artykule wskazuje na kompetencje izby. Posiada ona inicjatywę ustawodawczą. Przedkłada projekty ustaw izbie pierwszej, wychodzi z żądaniem ponownego rozpatrzenia uchwalonej wcześniej ustawy. Ponadto ma prawo do przedstawienia opinii izbie pierwszej w przedmiocie swoich kompetencji. Wówczas izba pierwsza musi wskazać, w jakim stopniu uwagi zostały zawarte w akcie prawnym. Przypomina to w swojej formie włoskie rady społeczno-gospodarcze (Konstytucja Słowenii, art. 97).

Najważniejszym uprawnieniem, którym została obdarzona izba, jest prawo do ustalenia weta zawieszającego wobec ustaw przyjętych przez pierwszą izbę przed jej promulgowaniem przez Prezydenta. Wtedy może zażądać rozpatrzenia ustawy po raz drugi (Konstytucja Słowenii, art. 91). Do jej zadań należy także złożenie wniosku o przeprowadzenie referendum lub dochodzenia o znaczeniu publicznym. Konstytucja Słowenii wskazuje, że może je zarządzić izba pierwsza na żądanie izby drugiej (Konstytucja Słowenii, art. 93 i 97).

Rada Państwa nie otrzymała konstytucyjnego prawa do złożenia wniosku o zmianę przepisów ustawy zasadniczej, nie bierze także udziału w postępowaniu, które ma na celu uchwalanie budżetu państwa. Nałożono na nią natomiast 
uprawnienie do składania wniosku do Trybunału Konstytucyjnego o ocenę konstytucyjności przepisów prawnych. Może z niego skorzystać, jeśli uzna, że chociaż jeden przepis jest niezgodny z ustawą zasadniczą (Mikuli, 2003, s. 32-34; Rybicki, 2012, s. 11).

W związku z ograniczonymi kompetencjami izby drugiej, to Zgromadzenie Parlamentarne wypełnia wszystkie kompetencje władzy ustawodawczej wobec wykonawczej (Mikuli, 2003, s. 32-34). W stosunku do władzy sądowniczej składa ona wnioski do Sądu Konstytucyjnego o stwierdzenie niekonstytucyjności przepisów prawa, a także legalności aktów wykonawczych. Z uwagi na szczególny charakter Rady Narodowej, relacje między izbami również nie należą do tradycyjnych. Co do zasady izby obradują oddzielnie i nie przewiduje się wspólnych posiedzeń parlamentu.

Izba druga zajmuje się współpracą międzynarodową - z ciałami reprezentującymi inne kraje w tym zakresie, ale także z organizacjami międzynarodowymi. Przedstawiciel Rady Narodowej przedstawia opinię izby na forum Zgromadzenia Narodowego. Po wejściu do Unii Europejskiej przedkłada ona także izbie pierwszej sprawy dotyczące wspólnoty. Rada zajmuje się problemami adekwatnymi do swojego składu, ale nie posiada swoich przedstawicieli w Parlamencie Europejskim (Mikuli, 2003, s. 32-34).

\section{ZAKOŃCZENIE}

Starając się odpowiedzieć na hipotezę powziętą we wstępie pracy, warto podkreślić, że kształt obu izb jest unikatowy w skali świata. Niewątpliwie izby wyróżniają się sposobem wyłaniania deputowanych, ale także nadanym im kompetencjom. Powoduje to dość oryginalną alternatywę dla porządku jednoizbowego. Izba druga w Bośni i Hercegowinie jest wyrazicielem reprezentacji trzech największych narodów. Należy sobie jednak zadać pytanie, dlaczego pominięto pozostałe, które choć występują w zdecydowanej mniejszości, to jednak pozbawione są swoich praw przez brak przedstawicieli w izbie. Co więcej, członkowie zgromadzenia nie są także wybierani za pomocą tego samego sposobu (model wyboru zależy od narodowości), co podważa sprawiedliwość w doborze reprezentacji izby. Skład Rady Narodów w Słowenii, prócz deputowanych wybranych lokalnie, to także wyrażenie reprezentacji jedynie głównych profesji.

O ile w przypadku Bośni i Hercegowiny, w moim przekonaniu, wybór struktury bikameralnej parlamentu jest słuszny, ponieważ kompetencje nadane Izbie 
Narodów są silne, a obie izby równorzędne względem siebie, o tyle w Słowenii pełni ona charakter doradczy czy konsultacyjny. Została ona wyraźnie odsunięta od realnej władzy. Należy więc pomyśleć nad realnym sensem zachowania tego ciała parlamentarnego i zastanowienia się, czy model unikameralny nie będzie atrakcyjniejszy. Można także skierować się ku poszerzeniu kompetencji na jej rzecz, poprzez chociażby nadanie prawa do procedowania ustaw w sprawach, które danych profesji (zawierających się w składzie izby) dotyczą.

Izba Narodów ma swoje określone i mocno osadzone kompetencje w całym systemie. Oczywiste jest potwierdzenie hipotezy pomocniczej o wypracowaniu własnej i oryginalnej konstrukcji izb, jednakże uważam, że w Bośni i Hercegowinie nie odpowiada ona potrzebom państwowo-politycznym.

Z uwagi na federatywny charakter państwa, skład izby mógłby ukształtować się w nawiązaniu do części składowych, gdzie swój wyraz będą miały poszczególne jednostki samorządu terytorialnego. Być może byłby to sposób na wyzbycie się podziału obywateli w państwie na trzy dominujące narodowości.

\section{BiBLIOGRAFIA:}

Biernat, T. (1978). Nauki polityczne jako dziedzina nauk społecznych. W: J. Wielgosz (red.). Podstawy nauk politycznych. Kraków: Wyd. COM SNP.

Konstytucja Bośni i Hercegowiny. (1995). Pobrane z: http://www.ccbh.ba/osnovni-akti/ ustav/?title=preambula.

Krysieniel, K. (2005). Słowenia. W: M. Barański (red.). Systemy polityczne państw Europy Środkowej i Wschodniej, Ustrój, organy władzy, partie polityczne (wyd. 2. rozszerzone). Katowice: Wydawnictwo Uniwersytetu Śląskiego.

Krysieniel, K. (2012). W cieniu Dayton, Bośnia i Hercegowina między etnokracją i demokracja konsolidacyjna. Warszawa: Wydawnictwo Sejmowe.

Markiewicz, T. (2008). Ewolucja Systemu politycznego Bośni i Hercegowiny. W: P. Czubik (red.). Bałkany u progu zjednoczonej Europy (s. 185-201). Kraków: Instytut Multimedialny.

Mansfeldová, Z. (2011). Central European Parliaments over Two Decades - Diminishing Stability? Parliaments in Czech Republic, Hungary, Poland, and Slovenia, Journal, Issue 2: Post-Communist Parliaments: Change and Stability in the Second Decade. The Journal of Legislative Studies, 17, 128-146.

Mikuli, P. ( 2003). Parlament Stowenii. Warszawa: Wydawnictwo Sejmowe.

Nystuten, G. (2005). Achieving Peace or Protecting Human Right? Conflict Between Norms Regarding Ethnic Discrimination in the Dayton Peace Agreement. Leiden: Martinus Nijhoff Pub.

Patyra, S. (2002). Republika Słowenii. W: E. Gdulewicz (red.). Ustroje państw współczesnych (s. 221-250). Warszawa: Wydawnictwo UMCS. 
Pioruńska, M. (2010). Przyczyny rozpadu Jugosławii w latach 90. XX wieku. Poznań: Wydawnictwo Naukowe SCRIPTORIUM.

Regulamin Izby Narodów: POSLOVNIK DOMA NARODA PARLAMENTARNE SKUPŠTINE BOSNE I HERCEGOVINE, Ustava Bosne i Hercegovine, Dom naroda Parlamentarne skupštine Bosne i Hercegovine. (2014) Pobrane z: https://www. parlament.ba/data/dokumenti/pdf/Poslovnik\%20doma\%20naroda\%20bs.pdf.

Rybicki, R. (2012). Podział władz w Stowenii. Wrocław: Wyd. Stefan Matlak.

Rycerska, I. (2003). Rozpad Jugosławii. Przyczyny i przebieg. Kielce: Wyd. Akademia Świętokrzyska.

Składowski, K. (2013). System rządów w Republice Chorwacji. Łódź: Wydawnictwo Uniwersytetu Łódzkiego.

Sokół, W., Grylak, B. (2005). System polityczny Słowenii. W: W. Sokół, M. Żmigrodzki (red.). Systemy polityczne państw Europy Środkowej i Wschodniej (s. 507-542). Lublin: Wydawnictwo UMCS.

Stanisławski, W. (2008). Bośnia i Hercegowina. W: R. Sadowski, J. Muś (red.). Bałkany Zachodnie a integracja europejska. Perspektywy i implikacje (s. 42-50). Warszawa: Urząd Komitetu Integracji Europejskiej.

Vlaisavlević, U. (2009). Bośnia i Hercegowina: ciągłość etnopolityki w wieku integracji europejskiej. W: M. Ebertowski (red.). Rok 1989 - 20 lat później: kraje postkomunistyczne a integracja europejska (s. 161-186). Warszawa: Fundacja im. Heinricha Bölla.

Wiatr, J.J. (1998). Słowenia: przykład udanej transformacji. Warszawa: Fund. im. Kazimierza Kelles-Krauza.

Winczorek, P. (tłum.). (2009). Konstytucja Republiki Słowenii. Warszawa: Wydawnictwo Sejmowe. 